\title{
Would the World Be a Better Place If One Were to Adopt a European Approach to State Immunity? Or, 'Soll am Europäischen Wesen die Staatenimmunität Genesen'?
}

\section{Andreas Zimmermann}

\begin{abstract}
This chapter argues not only that there is no European Sonderweg (or 'special way') when it comes to the law of state immunity but that there ought not to be one. Debates within The Hague Conference on Private International Law in the late 1990s and those leading to the adoption of the 2002 UN Convention on Jurisdictional Immunities of States, as well as the development of the EU Brussels Regulation on Jurisdiction and Enforcement, as amended in 2015, all demonstrate that state immunity was not meant to be limited by such treaties but 'safeguarded'. Likewise, there is no proof that regional European customary law limits state immunity when it comes to ius cogens violations, as Italy and (partly) Greece are the only European states denying state immunity in such cases while the European Court of Human Rights has, time and again, upheld a broad concept of state immunity. It therefore seems unlikely that in the foreseeable future a specific European customary law norm on state immunity will develop, especially given the lack of participation in such practice by those states most concerned by the matter, including Germany. This chapter considers the possible legal implications of the jurisprudence of the Italian Constitutional Court for European military operations (if such operations went beyond peacekeeping). These implications would mainly depend on the question of attribution: if one where to assume that acts undertaken within the framework of military operations led by the EU were to be, at least also, attributable to the troopcontributing member states, the respective troop-contributing state would be entitled to enjoy state immunity exactly to the same degree as in any kind of unilateral military operations. Additionally, some possible perspectives beyond Sentenza 238/2014 are examined, in particular concerning the redress awarded by domestic courts 'as long as' neither the German nor the international system grant equivalent protection to the victims of serious violations of international humanitarian law committed during
\end{abstract}

\footnotetext{
A. Zimmermann ( $\square)$

University of Potsdam, Faculty of Law, Potsdam, Germany

e-mail: andreas.zimmermann@uni-potsdam.de 
World War II. In the author's opinion, strengthening the jurisdiction of international courts and tribunals, bringing interstate cases for damages before the International Court of Justice, as well as providing for claims commissions where individual compensation might be sought for violations of international humanitarian law would be more useful and appropriate mechanisms than denying state immunity.

\section{Introduction}

Although this chapter addresses a somewhat colourful bundle of questions, all of them, one way or the other, relate to one overarching question: do specific European perspectives exist de lege lata-or at least should such perspectives exist de lege ferenda-when it comes to the law of state immunity in situations where serious violations of international law have been committed or where, more realistically in current circumstances, such violations are being alleged by the claimant? To get straight to the point, the blunt answer is a clear and simple 'no'. There is no European Sonderweg (or 'special way') when it comes to the law of state immunity, and there ought not to be one either. Rather, member states of the EU, and contracting parties to the European Convention on Human Rights (ECHR) more broadly, should continue to abide by universally recognized principles of state immunity, as having been confirmed by the International Court of Justice (ICJ) in its Jurisdictional Immunities Judgment on the matter. ${ }^{1}$ Accordingly, relevant treaty norms, including the ECHR and applicable secondary legislation of the EU, ${ }^{2}$ should continue to be interpreted and applied in line with currently applicable norms of customary and treaty law on the matter.

Having thus set the scene for the perspective adopted in this chapter, the following sections will delve into more specific issues surrounding the topic. First, a somewhat technical aspect will be addressed: the enforcement, in individual European states, of domestic judgments rendered contrary to traditional concepts of state immunity (section II). In particular, the debate within the Hague Conference on Private International Law in the late 1990s will be summarized since it was also of relevance for the debate on the 2004 UN Convention on Jurisdictional Immunities of States and Their Property (UN Convention on State Immunity) ${ }^{3}$ and the

\footnotetext{
${ }^{1}$ ICJ, Jurisdictional Immunities of the State (Germany v Italy: Greece intervening), Judgment of 3 February 2012, ICJ Reports 2012, 99, para 56 et seq.

${ }^{2}$ Cf Regulation (EC) No 805/2004 of the European Parliament and of the Council of 21 April 2004 creating a European Enforcement Order for Uncontested Claims, OJ vol 47, L143; Regulation (EC) No 1896/2006 of the European Parliament and of the Council of 12 December 2006 creating a European Order for Payment Procedures, OJ vol 49, L399; Regulation (EU) No 1215/2012 of the European Parliament and of the Council of 12 December 2012 on Jurisdiction and the Recognition and Enforcement of Judgments in Civil and Commercial Matters, OJ vol 55, L 351. For details on the latter, cf section II.2.

${ }^{3}$ UN Convention on Jurisdictional Immunities of States and Their Property (2 December 2004), UN Doc A/RES/59/38, UN Doc A/59/49, 486 (not yet in force).
} 
development of the Brussels Regulation. Second, the possible development of specific rules of regional customary law on the matter will be discussed (section III). Third, the legal implications of the jurisprudence of the Italian Constitutional Court (ItCC) for European military operations, and in particular for military operations under the auspices of the EU, will be analyzed (section IV). Finally, the chapter will conclude with some remarks on possible European perspectives beyond Sentenza 238/2014 (section V).

\section{Enforcing Foreign Judgments That Have Not Respected State Immunity}

\section{The Hague Conference on Private International Law $^{4}$}

It was in 1996 that the Hague Conference on Private International Law, with important input from European states and from the EU, decided to 'include in the agenda of the $19^{\text {th }}$ session the question of (..) recognition and enforcement of foreign judgments in civil and commercial matters'. 5 This led to the creation of a Special Commission to come up with a first draft for a convention. The Special Commission's 1999 draft included Article 18(3) that, if adopted, would have provided, as one option, for the possibility of exercising universal jurisdiction in civil matters with respect to conduct constituting genocide, crimes against humanity, war crimes, or other serious crimes against a natural person under international law, respectively with regard to ius cogens violations. ${ }^{6}$ It is worth recalling that the draft provision had also provided that the envisaged broad acceptance of jurisdiction would only apply, at least as far as the two latter categories of violations of international law are concerned (namely serious crimes under international law and ius cogens violations other than genocide, war crimes and crimes against humanity), 'if the party seeking relief is exposed to a risk of a denial of justice

\footnotetext{
${ }^{4} \mathrm{Cf}$, generally on the conference, www.hcch.net/en/home.

${ }^{5} \mathrm{Cf}$ Catherine Kessedjian, 'International Jurisdiction and Foreign Judgments in Civil and Commercial Matters', Preliminary Document No 7 (April 1997), para 26, available at https://assets.hcch.net/ docs/76852ce3-a967-42e4-94f5-24be4289d1e5.pdf.

${ }^{6}$ Hague Conference on Private International Law, Preliminary Draft Convention on Jurisdiction and Foreign Judgments in Civil and Commercial Matters, 30 October 1999, text to be found in Stefan Rinke, Schadensersatzklagen gegen Staaten wegen schwerer Menschenrechtsverletzungen im Europäischen Zivilprozessrecht, (Berlin: BWV Verlag 2016), 128 or the Report by Peter Nygh/ Fausto Pocar concerning the Preliminary Draft Convention on Jurisdiction and Foreign Judgments in Civil and Commercial Matters, adopted by the Special Commission, Preliminary Document No 11 (August 2000), available at https://assets.hcch.net/upload/wop/jdgmpd11.pdf, 10.
} 
because proceedings in another state are not possible or cannot reasonably be required'?

This draft provision thus foreshadowed the last-resort argument made later by Italy during the ICJ proceedings brought by Germany for alleged violations of Germany's state immunity. ${ }^{8}$ It ought to be noted, however, that this provision, as Peter Nygh and Fausto Pocar's underlying explanatory report had made clear, ${ }^{9}$ was only meant to govern jurisdictional issues while state immunity was not meant to be limited by the envisaged treaty. This was confirmed by its draft Article 1(4), which in broad terms had provided that '[n]othing in this Convention affects the privileges and immunities of sovereign States or of entities of sovereign States, or of international organizations'. ${ }^{10}$ It also ought to be noted that the International Law Commission (ILC) was, during the very same period, working on a draft convention on the jurisdictional immunities of states, ${ }^{11}$ which, as is well known, later led to the adoption of the UN Convention on the matter. ${ }^{12}$ The ILC's draft convention similarly did not include any reference to a possible limitation on state immunity in cases of serious violations of international law. ${ }^{13}$ Notwithstanding this development within the ILC, the 2001 draft Hague convention, as submitted to and discussed by The Hague diplomatic conference, had retained, mutatis mutandis, identical language to the same effect as the 1999 draft by the then Special Commission. In other words, it had retained the concept of state immunity even when it comes to instances of genocide, war crimes, and other violations of ius cogens.

What is brought to light by this development is that even a possible acceptance of the exercise of universal jurisdiction in matters such as genocide, crimes against humanity or war crimes, in the envisaged future convention on the recognition and enforcement of foreign judgments, would not have been meant to curtail traditional concepts of state immunity even when it comes to serious violations of international law. What is more, as is evident from the fate of the draft, is that even on those issues no consensus could be reached which led in 2005 to the adoption of a mere convention on choice of court agreements. ${ }^{14}$

\footnotetext{
${ }^{7}$ Ibid.

${ }^{8} \mathrm{ICJ}$, Jurisdictional Immunities (Germany v Italy: Greece intervening) (n 1), para 98 et seq.

${ }^{9} \mathrm{Cf}$ Nygh/Pocar, 'Report concerning the Preliminary Draft Convention' 2000 (n 6).

${ }^{10}$ Ibid, 4.

${ }^{11}$ Yearbook of the International Law Commission II, part 2 (1999), chapter VII, 127 et seq.

${ }^{12} \mathrm{UN}$ Convention on Jurisdictional Immunities, 2004 (n 3).

${ }^{13} \mathrm{Cf}$ Rinke, Schadensersatzklagen 2016 (n 6), 128 et seq; see also Gerhard Hafner, 'Das Übereinkommen der Vereinten Nationen über die Immunität der Staaten und ihres Vermögens von der Gerichtsbarkeit', Zeitschrift für öffentliches Recht 61 (2006), 381-395, at 394.

${ }^{14}$ Convention on Choice of Court Agreements, The Hague Conference on Private International Law, 30 June 2005, available at www.hcch.net/en/instruments/conventions/full-text/?cid=98.
} 


\section{Brussels Ia Regulation}

Turning now to developments within the framework of the EU more specifically, as is well known, the Brussels Regulation was amended in 2015. Commonly referred to as the Brussels Ia Regulation, it built on the Brussels and Lugano Conventions, ${ }^{15}$ as well as earlier versions of the Brussels Regulation itself, ${ }^{16}$ and significantly facilitates the enforcement of judgments on civil and commercial matters rendered in another EU member state by providing for a quasi-automatic system of enforcement of such judgments. ${ }^{17}$ This raises the question of whether under the Brussels Ia Regulation a judgment by a domestic court of one member state denying state immunity when it comes to alleged violations of ius cogens committed by a foreign armed force is enforceable in other EU member states. If that were the case, this would clearly be indicative of an acceptance by the EU of a special regime of a more limited concept of state immunity.

Before entering into details, it should be noted that the preambular paragraph 38 of said Regulation confirms - in the view of its drafters-that it 'respects fundamental rights and observes the principles recognised in the Charter of Fundamental Rights of the European Union, in particular the right to an effective remedy and to a fair trial guaranteed in Article 47 of the Charter'. After having thus confirmed that the Regulation stands in line with the right to an effective remedy, the Regulation, as amended in 2015, now expressis verbis settles that it 'shall not extend, in particular, to (...) the liability of the State for acts and omissions in the exercise of State authority (acta iure imperii), ${ }^{18}$

The amended version, therefore, now also expressis verbis reiterates what the European Court of Justice (ECJ) had already decided in 2007 under the then applicable (older) version of the Brussels Regulation in the Kalavryta case brought by Ms Lechouritou against Germany, and involving a claim for damages related to a massacre committed by the German army in 1943 against Greek civilians. ${ }^{19}$ The ECJ had then decided that such claims do not amount to civil and commercial claims within the meaning of the Brussels system providing for the intra-Union enforcement of judgments.

However, what is brought out by the interplay between the preamble of the amended Regulation and the exclusion from its scope of acta jure imperii-such

\footnotetext{
${ }^{15}$ Brussels Convention on Jurisdiction and the Enforcement of Judgments in Civil and Commercial Matters, 27 September 1968, Official Journal of the European Communities L 299, 31 December 1972; Convention on Jurisdiction and the Enforcement of Judgments in Civil and Commercial Matters, 16 September 1988, Official Journal of the European Communities, vol 31, L 319, 25 November 1988.

${ }^{16}$ Council Regulation (EC) No 44/2001 of 22 December 2000 on Jurisdiction and the Recognition and Enforcement of Judgments in Civil and Commercial Matters [2001] OJ L12.

${ }^{17} \mathrm{Cf}$, for details, preambular para 2, Arts 36(1), 39, and 40 of Regulation (EU) 1215/2012 on Judgments in Civil and Commercial Matters (n 2).

${ }^{18}$ Art 1 of Regulation (EU) 1215/2012 on Judgments in Civil and Commercial Matters (n 2).

${ }^{19}$ ECJ, Lechouritou and Others, Judgment of 15 February 2007, Case No C-292/05, I-1540.
} 
as acts of armed forces, in particular when they take place within the framework of armed conflicts ${ }^{20}$ - is that the Brussels Regulation, as amended, wanted to 'safeguard' traditional rules of state immunity. What is more, the drafters of the amended Regulation were obviously aware of the then recent judgment of the ICJ in the Jurisdictional Immunities (Germany $v$ Italy) case. They were also aware of the previously unsuccessful attempts to use the Brussels Regulation to enforce Greek court decisions in Italy, ${ }^{21}$ which had set aside Germany's state immunity in cases involving war crimes but which could not be enforced in Greece itself for lack of consent by the Greek Minister of Justice. ${ }^{22}$ Accordingly, the amendment of the Brussels Regulation in 2015, when read in conjunction with the above-mentioned preamble to the Regulation, must be seen as evidence of the conviction of EU member states that the traditional rules of state immunity, including when it comes to ius cogens violations, are indeed compatible with the international and European rule of law.

\section{Regional European Customary Law on State Immunity?}

International law since the judgment of the ICJ in the Asylum (Colombia v Peru) case recognizes - be it only as a matter of principle - the concept, the notion, and the possibility of regional customary law. ${ }^{23}$ Yet, as the Court stated, the existence of any such rule presupposes that ' $[\mathrm{t}]$ he Party which relies on a custom of this kind must prove (...) that the rule invoked by it is in accordance with a constant and uniform usage practised by the States in question', and that this statement, the Court confirmed, 'follow[ed] from Article 38 of the Statute of the Court, which refers to international custom "as evidence of a general practice accepted as law". 24

Accordingly, in the case at hand, in order to argue in favour of a rule of regional customary law limiting state immunity when it comes to ius cogens violations, one would have to show coherent and consistent state practice by European states and thus confirming the existence of such a rule (or the emergence thereof). Yet, even if one were to limit oneself to the practice of EU member states, which in itself would be problematic since EU member states presumably do not even constitute a 'region' for purposes of general international law, there are only singular cases where no state immunity has been granted even where the underlying issues related to serious

\footnotetext{
${ }^{20}$ During the ICJ proceedings leading to the Jurisdictional Immunities Judgment, neither of the two parties argued that such acts did not amount to acta iure imperii; see ICJ, Jurisdictional Immunities (n 1), 99, para 60 et seq.

${ }^{21} \mathrm{Cf}$ ICJ, Jurisdictional Immunities (n 1), 99, para 33 et seq.

${ }^{22}$ Enforcement against a foreign state requires the consent of the Minister of Justice under Art 923 of the Greek Code of Civil Procedure, which was not granted.

${ }^{23}$ ICJ, Asylum Case (Colombia v Peru), Judgment of 20 November 1950, ICJ Reports 1950, 266, 276 et seq.

${ }^{24}$ Ibid.
} 
violations of either international humanitarian law or human rights law. Even in the case of Italy, the Italian government and Italian courts continue to take the position that Germany enjoys immunity when it comes to the execution of the underlying judgments, ${ }^{25}$ while the judgment of the $\mathrm{ItCC}^{26}$ did not base its decision on international law but rather exclusively on domestic Italian law. ${ }^{27}$

Moreover, the 2012 ICJ Judgment in turn had made frequent reference specifically to decisions of European courts, including judgments by Polish, ${ }^{28}$ Slovenian, ${ }^{29}$ Belgian $^{30}$ and Serbian courts, ${ }^{31}$ and on that basis had upheld Germany's state immunity even in the face of serious violations of the laws and customs of war. ${ }^{32}$ Hence, at most there is practice by only two European states denying state immunity in cases of ius cogens violations, namely Italy and possibly Greece (notwithstanding the Greek government not granting the necessary permission to enforce a judgment of Greek courts against Germany, which then led to an attempt to have the said judgment enforced in Italy). Even in those instances, this practice is limited to the practice of national courts, rather than that of either the executive or the legislative branch, which in and of itself raises fundamental questions as to the notion and concept of state practice within the meaning of Article 38 of the ICJ Statute. ${ }^{33}$

Furthermore, four European states-Finland, Sweden, Norway, and Italy-also made it clear when ratifying the 2004 UN Convention on State Immunity that in their respective understanding the foreign tort exception to state immunity under the Convention does not apply when it comes to activities of armed forces during an

\footnotetext{
${ }^{25}$ ICJ, Jurisdictional Immunities (n 1), 99, para 112; Cf also Karin Oellers-Frahm, ‘A Never-Ending Story: The International Court of Justice-The Italian Constitutional Court-Italian Tribunals and the Question of Immunity', Heidelberg Journal of International Law 76 (2016), 193-202, at 195 et seq. ${ }^{26}$ Corte Costituzionale, Judgment of 22 October 2014, No 238/2014.

${ }^{27} \mathrm{Ibid}$, Conclusions in Point of Law, para 3. For details on the approach taken by the Constitutional Court cf, eg, Raffaela Kunz, 'The Italian Constitutional Court and "Constructive Contestation": A Miscarried Attempt?', Journal of International Criminal Justice 14 (2016), 621-627, at 623 et seq.

${ }^{28}$ Supreme Court of Poland, Natoniewski v Federal Republic of Germany, Judgment of 29 October 2010, Polish Yearbook of International Law, vol XXX, 2010, 299.

${ }^{29}$ Constitutional Court of Slovenia, Decision of 8 March 2001, Case No Up-13/99, Constitutional Court, para 13.

${ }^{30}$ Court of First Instance of Ghent, Botelberghe v German State, Judgment of 18 February 2000.

${ }^{31}$ Court of First Instance of Leskovac, Judgment of 1 November 2001.

${ }^{32}$ ICJ, Jurisdictional Immunities (n 1), 99, cites: ECtHR, McElhinney v Ireland, Grand Chamber Judgment of 21 November 2001, Application No 31253/96; ECtHR, Grosz v France, Decision of 16 June 2009, Application No 14717/06; and Kalogeropoulou and Others v Greece and Germany, Decision of 12 December 2002, Application No 59021/00. Cf also the ICJ's conclusion in para 78.

${ }^{33}$ The implications of inconsistent state practice in the identification of customary international law are also addressed in Draft Conclusion 7 and the accompanying commentary adopted by the ILC in its sixty-eighth session in the framework of its on-going project on the 'Identification of customary international law', cf Report of the International Law Commission, Sixty-Eighth Session (2 May-10 June and 4 July-12 August 2016), General Assembly Official Records, Seventy-First Session Supplement No 10 (A/71/10), 92 et seq. See also Paolo Palchetti, chapter 'Right of Access to (Italian) Courts über alles?', in this volume.
} 
armed conflict, and indeed even beyond as far as 'activities undertaken by military forces of a State in the exercise of their official duties' are concerned. ${ }^{34}$ Besides, one might also recall the well-known Article 31 of the European Convention on the matter ${ }^{35}$ which expressis verbis contains the very same idea. ${ }^{36}$ Finally, the regional European human rights institution, namely the European Court of Human Rights (ECtHR), has also time and again upheld a broad concept of state immunity. As a matter of fact, it did so even in the face of ius cogens violations like torture. ${ }^{37}$

Put otherwise, one might be tempted to say that if there is one region in the world where the traditional concept of state immunity has been upheld the most, it is Europe. If one were to take a different position, be it only arguendo, namely that there indeed was a European tendency to restrict state immunity when it comes to violations of international humanitarian law or human rights law, the necessary requirements for the creation of a new and more limited rule of customary international law on the matter within both a short period of time and the parameters of the ICJ's North Sea Continental Shelf (Germany/Netherlands) case are clearly not fulfilled. ${ }^{38}$ Indeed, this is true not only for lack of a virtually uniform practice but also for lack of participation in such practice by those states most concerned by the matter, which in the case at hand would have to include Germany as being particularly concerned by issues of state immunity relating to war crimes and other similar violations of international law committed during World War II (WWII).

Given this situation, it seems barely imaginable that in the foreseeable future a specific European customary law norm on state immunity could develop. Rather, it seems that the EU and its member states, as well as other member states of the Council of Europe, like Norway, Turkey, or the Russian Federation, continue to rely on a broad concept of state immunity. This is also brought out, inter alia, by the recent démarches of the EU against the so-called US Justice Against Sponsors of

\footnotetext{
${ }^{34} \mathrm{Cf}$ UN Convention on Jurisdictional Immunities, 2004 (n 3), Declarations and Reservations available at https://treaties.un.org/doc/Publication/MTDSG/Volume\%20I/Chapter\%20III/III-13. en.pdf.

${ }^{35}$ Art 31 of the European Convention on State Immunity, 16 May 1972, ETS No 074, reads: 'Nothing in this Convention shall affect any immunities or privileges enjoyed by a Contracting State in respect of anything done or omitted to be done by, or in relation to, its armed forces when on the territory of another Contracting State.'

${ }^{36}$ It should also be mentioned that, as noted by the ICJ in its Jurisdictional Immunities Judgment, courts in Belgium (Court of First Instance of Ghent, Botelberghe v German State, Judgment of 18 February 2000), Ireland (Supreme Court, McElhinney $v$ Williams, Judgment of 15 December 1995, 3 Irish Reports 382), Slovenia (Constitutional Court, Case No Up-13/99, para 13), Greece (Margellos v Federal Republic of Germany, Case No 6/2002, ILR, vol 129, 529) and Poland (Supreme Court of Poland, Natoniewski v Federal Republic of Germany, Polish Yearbook of International Law, vol XXX, 2010,299) all held that that the immunity of a state for torts committed by its armed forces is unaffected by Art 11 of the Convention by virtue of its Art 31; cf ICJ, Jurisdictional Immunities (n 1), 99, at para 68.

${ }^{37}$ ECtHR, Jones and Others $v$ The United Kingdom, Judgment of 14 January 2014, Applications Nos 34356/06 and 40528/06, para 93.

${ }^{38}$ ICJ, North Sea Continental Shelf (Federal Republic of Germany/Netherlands), Judgment of 20 February 1969, ICJ Reports 1969, 3, at para 74.
} 
Terrorism Act (JASTA), ${ }^{39}$ which, by way of amending the US Foreign Sovereign Immunities Act, significantly narrows the scope of foreign sovereign immunity under domestic US law- and it does so in violation of international law. ${ }^{40}$

As a matter of fact, out of the 14 European states having so far ratified UN Convention on State Immunity, ${ }^{41}$ only Switzerland has formally taken the position that the said treaty is without prejudice to developments in international law regarding pecuniary compensation for human rights violations; ${ }^{42}$ while Italy, when ratifying the Convention, merely referred to the necessity to interpret the treaty in line with human rights law. ${ }^{43}$ This acceptance by the vast majority of ratifying European states of the 2004 UN Convention, which does not contain an ius cogens or some other form of human rights exception, once again confirms the general European perspective on the matter, as outlined above. It is even more telling that six of those ratifying European states have done so after the Jurisdictional Immunities Judgment between Germany and Italy had been rendered ${ }^{44}$ —and they did so without entering any reservation or formal declaration as to the 'conservative' interpretation of the current status of the rules of state immunity by the ICJ.

\section{Possible Legal Implications of the Jurisprudence of the Italian Constitutional Court for European Military Operations}

The jurisprudence of the ItCC might have particular implications for European military operations, namely for military operations under the auspices of the EU, given that EU states might face a denial of their state immunity when their troops

\footnotetext{
${ }^{39}$ US, Justice Against Sponsors of Terrorism Act, 28 September 2016, Public Law No 114-222, available at www.gpo.gov/fdsys/pkg/BILLS-114s2040enr/html/BILLS-114s2040enr.htm.

${ }^{40} \mathrm{EU}$, Delegation to the United States of America, note to the US Department of State of 9 September 2016, available at www.washingtonpost.com/news/powerpost/wp-content/uploads/ sites/47/2016/09/EU-on-JASTA.pdf. See also Riccardo Pavoni, chapter 'A Plea for Legal Peace', in this volume.

${ }^{41}$ Those are: Austria, Czech Republic, Finland, France, Italy, Latvia, Liechtenstein, Norway, Portugal, Romania, Slovakia, Spain, Sweden and Switzerland. Cf UN Convention on Jurisdictional Immunities, 2004 (n 3).

${ }^{42}$ Ibid, upon ratification on 16 April 2010, Switzerland declared: 'Switzerland considers that article 12 does not govern the question of pecuniary compensation for serious human rights violations which are alleged to be attributable to a state and are committed outside the state of the forum. Consequently, this Convention is without prejudice to developments in international law in this regard.'

${ }^{43}$ Ibid, upon ratification on 6 May 2013, Italy declared: '[T]he Italian Republic wishes to underline that Italy understands that the Convention will be interpreted and applied in accordance with the principles of international law and, in particular, with the principles concerning the protection of human rights from serious violations.'

${ }^{44}$ Ibid, those are Czech Republic, Finland, Italy, Latvia, Liechtenstein and Slovakia.
} 
allegedly commit violations of international humanitarian law during such operations. It should first be noted, however, that it is highly unlikely that European armed forces and their member states will commit violations of international humanitarian law amounting to ius cogens violations akin to the war crimes that gave rise to the jurisprudence of the Italian courts in the first place. Hence, most probably, the issue of a possible ius cogens exception will hopefully remain a mere academic issue when it comes to the realities of current European military operations.

Secondly, and this is a somewhat more difficult question to answer, it is doubtful whether the result reached by the ICJ in its Jurisdictional Immunities Judgment confirming state immunity for belligerent acts ${ }^{45}$ would also apply to activities of armed forces not amounting to participation in an armed conflict as a belligerent party but rather, for example, to acts forming part of a peacekeeping operation. This would then bring back the issue of the scope and status under customary law of the foreign tort exception. Again, it ought to be noted that several European states, including Italy, have taken the position that the counter-exception to the foreign tort exception should be broadly defined as covering all forms of military activities and even those beyond the scope of armed conflicts. ${ }^{46}$

In any case, any debate about the extent of state immunity when it comes to European military operations would first and foremost, and as a preliminary matter, have to tackle the issue of attribution. ${ }^{47}$ If European military operations, conducted under the auspices of the EU, were to be attributed to either the EU or, in the case of an underlying mandate by the Security Council, to the $\mathrm{UN}^{48}$ in line with the somewhat problematic jurisprudence of the ECtHR in the Behrami and Behrami $v$ France and Saramati v France, Germany and Norway cases, ${ }^{49}$ the question of state responsibility would obviously not arise. Yet, as the domestic proceedings in the Netherlands concerning the UN peacekeeping operation in Bosnia and Herzegovina have confirmed, mutatis mutandis, parallel issues to the immunity of international organizations might nevertheless come to light. ${ }^{50}$ It ought to be noted, however, that the Protocol on the Privileges and Immunities of the European Union, annexed to the

\footnotetext{
${ }^{45}$ ICJ, Jurisdictional Immunities (n 1), 99, at para 139, findings (1) and (3).

${ }^{46}$ Those are Finland, Italy, Norway and Sweden. See Convention on Jurisdictional Immunities, 2004 (n 3).

${ }^{47} \mathrm{Cf}$ Aurel Sari/Ramses A Wessel, 'International Responsibility for EU Military Operations: Finding the EU's Place in the Global Accountability Regime', in Bart Van Vooren/Steven Blockmans/Jan Wouters (eds), The EU's Role in Global Governance: The Legal Dimension (Oxford: OUP 2013), 126-141.

${ }^{48} \mathrm{Cf}$ Terry D Gill, 'Legal Aspects of the Transfer of Authority in UN Peace Operations', Netherlands Yearbook of International Law 42 (2011), 37-68, at 53 et seq.

${ }^{49}$ ECtHR, Behrami and Behrami v France, Grand Chamber Decision of 31 May 2007, Application No 71412/01 and ECtHR, Saramati v France, Germany and Norway, Grand Chamber Decision of 2 May 2007, Application No 78166/01.

${ }^{50}$ ECtHR Behrami and Behrami v France (n 49) and ECtHR, Saramati v France, Germany and Norway, (n 49). Cf Gill, 'Legal Aspects of the Transfer of Authority in UN Peace Operations' 2011 (n 48), 39.
} 
Treaty of Nice, ${ }^{51}$ does not as such provide for a general immunity of the EU at least when it comes to civil proceedings for damages brought before civil courts of an EU member state.

If one were to assume, however, that acts as part of military operations led by the EU were to be at least also attributable to the troop-contributing member states, as was the position taken by German courts concerning military operations conducted off the coast of Somalia within the framework of the European Union Naval Force (EU NAVFOR) ${ }^{52}$ no specific issues of state immunity would arise. Rather, the respective troop-contributing state would be entitled to enjoy state immunity to the same degree as in any kind of unilateral military operation. It is again interesting to note that Italy, when ratifying the 2004 UN Convention on State Immunity, expressly reiterated that-in its view-the Convention does not set aside 'special immunity regimes, including the ones concerning the status of armed forces and associated personnel following the armed forces, ${ }^{53}$ and it is submitted that this is completely in line with customary law. Accordingly, given that European armed forces would in most cases and including those like Afghanistan, where they are involved in actual fighting, act within the framework of a status of forces agreement concluded with the relevant territorial state specifically providing for the immunity of the respective European state, the issue would be moot since any such European state involved in a military operation would then continue to be entitled to fullyfledged immunity as a matter of treaty law.

Besides, to the extent that a domestic court of the territorial state with which a status of forces agreement providing for immunity has been concluded would have to decide the matter, setting aside such treaty-based immunity would not only require arguing that there is no state immunity in such cases but would have to argue that the alleged customary rule setting aside state immunity in case of alleged war crimes was in and of itself also of an ius cogens character. Such an argument, while being in line with the general thrust of the judgment of the ItCC, ${ }^{54}$ would, however, necessarily assume another bold step not supported by actual state practice.

In any case, it is worth noting that at least when it comes to European military operations in the strict sense, namely those undertaken under the auspices of the EU rather than operations within the framework of NATO but involving European states, the respective status of forces agreements concluded by the EU provide as a matter of routine for an individual right to seize a claims commission, followed by some form of arbitration. For example, the Agreement between the European Union

\footnotetext{
${ }^{51}$ Protocol (No 7) on the Privileges and Immunities of the European Union, annexed to the Treaty on European Union ('Treaty of Nice'), 13 December 2007, Official Journal of the European Union, vol 55, C 326/266.

${ }^{52} \mathrm{Cf}$, inter alia, Higher Administrative Court of Nordrhein-Westfalen, Judgment of 18 September 2014, 4 A 2948/11, DVB1 2015, 375-379, findings (Leitsätze) (1), (2) and (3).

${ }^{53}$ Declaration by the Italian Republic concerning the UN Convention on Jurisdictional Immunities, 2004 (n 3), made upon ratification in date of 6 May 2013, available at https://treaties.un.org/doc/ Publication/MTDSG/Volume\%20I/Chapter\%20III/III-13.en.pdf.

${ }^{54}$ ItCC, Judgment 238/2014 (n 26).
} 
and the Republic of Uganda on the Status of the European Union-led Mission in Uganda, ${ }^{55}$ regulating the legal status of the European Union Training Mission Somalia (EUTM) in Uganda, while confirming in its Article 5(3) that EUTM Somalia 'shall enjoy immunity from every form of legal process' at the same time provides in its Article 15 for the setting up of a claims commission, where claims by individuals can be brought, as well as for the creation of an arbitral tribunal, should the claims process fail to adequately address alleged individual damages. In such a scenario the last resort argument, as submitted by Italy in the ICJ proceedings brought by Germany, ${ }^{56}$ and somewhat also reflected in the judgment of the ItCC here under consideration, ${ }^{57}$ would no longer be of relevance, given the alternative to setting aside state immunity. In most situations with a deployment of troops under the auspices of the EU, the issue underlying Sentenza 238/2014 is thus somewhat academic in nature.

\section{Further Perspectives Beyond Sentenza 238/2014}

Obviously, the unfortunate approach chosen by the ItCC of disregarding the international legal obligations of Italy to implement a binding judgment of an international court or tribunal is not unique. It suffices to refer to the examples of the 2008 judgment of the US Supreme Court in Medellin v Texas ${ }^{58}$ (setting aside the effects of the ICJ judgment in Avena and Other Mexican Nationals, Mexico $v$ United States of America), ${ }^{59}$ or the more recent decision of the Russian Constitutional Court in the Yukos case. ${ }^{60}$ Just like the German Federal Constitutional Court, which had unfortunately in the past-albeit as a matter of principled approach only-mutatis mutandis chosen the collision course with the $\mathrm{ECJ}^{61}$ and later the

\footnotetext{
${ }^{55}$ Agreement between the European Union and the Republic of Uganda on the Status of the European Union-led Mission in Uganda, entered into force 12 August 2010, OJ L221/2, available at http://ec.europa.eu/world/agreements/prepareCreateTreatiesWorkspace/treatiesGeneralData.do? step $=0 \&$ redirect $=$ true $\&$ treaty $I d=9781$.

${ }^{56} \mathrm{ICJ}$, Jurisdictional Immunities (n 1), 99, at paras 98-104.

${ }^{57}$ ItCC, Judgment 238/2014 (n 26), Conclusions in Point of Law, para 3.4.

${ }^{58}$ US Supreme Court, Medellín v Texas, Judgment of 25 March 2008, No 06-984, available at https://supreme.justia.com/cases/federal/us/552/491/.

${ }^{59} \mathrm{ICJ}$, Avena and Other Mexican Nationals (Mexico v United States of America), Judgment of 31 March 2004, ICJ Reports 2004, 12.

${ }^{60}$ Russian Constitutional Court, Judgment of 19 January 2017, No 1-П/2017. See also, on the decision, Matthias Hartwig, 'Vom Dialog zum Disput? Verfassungsrecht vs. Europäische Menschenrechtskonvention-Der Fall der Russländischen Föderation', Europäische GrundrechteZeitschrift 44 (2017), 1-23.

${ }^{61}$ Bundesverfassungsgericht, Order of 22 October 1986, 2 BvR 197/83, BVerfGE 73, 339 (Solange II), English version: (1984) Case 345/82, [1987] 3 CMLR 225; Bundesverfassungsgericht, Judgment of 12 October 1993, 2 BvR 2134/92, BVerfGE 89, 155 (Maastricht Judgment).
} 
ECtHR, ${ }^{62}$ the course chosen by the ItCC has similarly not (yet) led to a concrete collision with the principal judicial organ of the UN. Such a collision would only occur if concrete steps were now taken to execute judgments for damages against German state property located in Italy and if Germany were to then start renewed proceedings before the ICJ, which could possibly lead to another ICJ judgment most probably reconfirming the 2012 ICJ Judgment. Hopefully such a collision can be avoided.

This leads to the question of whether the redress awarded by domestic (Italian) courts 'as long as' neither the German nor the international system grant equivalent protection to the victims of serious violations of international humanitarian law committed during WWII is necessary or at least tolerable. For instance, this raises the issue of whether indeed such individual claims do exist in the first place as a matter of the current international lex lata, which one might say is doubtful. Even if this were the case, such individual claims might have already been satisfied under previous interstate agreements or in the meantime might have been subject to some other form of prescription one way or the other.

While these questions would go beyond the scope of this chapter, one has to ask more broadly whether it truly makes sense at the current stage of international law and currently prevailing political developments to take bold steps like recognizing an individual right to compensation for such violations (and even where such violations have been committed more than 70 years ago) combined with denying immunity to the state concerned. The Pandora's box argument, while having been repeated time and again, ${ }^{63}$ is obvious: does it really make sense, for example, to have Georgian courts decide cases against the Russian Federation for alleged violations of international humanitarian law during the 2008 armed conflict — and then obviously also vice-versa-with almost 'automatic', yet completely contrary, results on the merits? Would this constitute an improvement of the international legal order, and would such a development truly foster the international rule of law?

Rather, the way forward-be it only for future cases-should be to enlarge and strengthen the jurisdiction of international courts and tribunals, either those that provide access to individuals or that have some form of compulsory jurisdiction. The European Convention for the Peaceful Settlement of Disputes certainly forms part of such an attempt, which could not be invoked by Italy as a jurisdictional basis for its counter-claim for reasons ratione temporis. ${ }^{64}$ That is to say: if a similar scenario of violations of international humanitarian law was to arise again today between two or more of the contracting parties of the said Convention, and it is hoped that this will

\footnotetext{
${ }^{62}$ Bundesverfassungsgericht, Order of 14 October 2004, 2 BvR 1481/04, BVerfGE 111, 307 (Görgülü); English translation by the Court, available at www.bverfg.de/entscheidungen/ rs20041014_2bvr148104en.html.

${ }^{63}$ Andreas Zimmermann, 'Das Völkerrecht stärken!', Die Tageszeitung (13 September 2011), available at http://www.taz.de/!5112119/.

${ }^{64} \mathrm{ICJ}$, Jurisdictional Immunities (n 1), 99, para 44.
} 
not happen, the underlying interstate case for damages could be brought, and rightly so, before the ICJ. It is submitted that this might be the right way forward.

In the same vein, providing for claims commissions might also be a useful and an appropriate mechanism provided the parties involved are indeed able and willing to follow up on such a process. ${ }^{65}$

This leads to a final question: what lessons ought to be learned when it comes to a possible dialogue between domestic and constitutional courts on the one hand, and international courts on the other? In the author's understanding, international courts not only constitute a capstone but also a cornerstone of the construction of international law. Once such a cornerstone is removed or damaged-and unfortunately, we currently see many instances, benevolent or not, to that effect throughout the world - the danger arises that the whole edifice if not collapses then at least begins to crack. Hence, every attempt should be made not to question their authority even more so since such international judicial institutions by their very nature have the clear advantage of being by far furthest away from domestic political pressures and sentiments.

In summary, one might say that European states, as well as European (constitutional) courts, should not straightforwardly follow Frank Sinatra's tempting example, who in his 1969 song 'My Way' told us that he had not acted 'in a shy way', that he 'had to say the things he truly felt' and not 'the words of one who kneels', and that 'the record therefore showed that he had to take the blows' in order to 'do it my way' ${ }^{66}$ Domestic courts, and even more so the highest courts of democratic and rule-based countries, do not only have a responsibility to their own constitutional order but also more broadly to the international legal order. Hence, such courts, but also Europe more generally, should try to avoid deciding matters of state immunity 'their own way' because it is not only them that would have to take the blow, but such blows could threaten to undermine international law and the international rule of law at large.

\section{References}

Gill, Terry D, 'Legal Aspects of the Transfer of Authority in UN Peace Operations', Netherlands Yearbook of International Law 42 (2011), 37-68

Hafner, Gerhard, 'Das Übereinkommen der Vereinten Nationen über die Immunität der Staaten und ihres Vermögens von der Gerichtsbarkeit', Zeitschrift für öffentliches Recht 61 (2006), 381-395

Hartwig, Matthias, 'Vom Dialog zum Disput? Verfassungsrecht vs. Europäische Menschenrechtskonvention-Der Fall der Russländischen Föderation', Europäische Grundrechte-Zeitschrift 44 (2017), 1-23.

Kunz, Raffaela, 'The Italian Constitutional Court and "Constructive Contestation": A Miscarried Attempt?', Journal of International Criminal Justice 14 (2016), 621-627

\footnotetext{
${ }^{65}$ Eritrea-Ethiopia Claims Commission, Eritrea/Ethiopia, Partial Award of 19 December 2005, Ius Ad Bellum-Ethiopia's Claims 1-8, available at https://pcacases.com/web/sendAttach/763.

${ }^{66}$ Frank Sinatra, 'My Way', available at https://www.youtube.com/watch?v=qQzdAsjWGPg.
} 
Oellers-Frahm, Karin, 'A Never-Ending Story: The International Court of Justice-The Italian Constitutional Court-Italian Tribunals and the Question of Immunity', Heidelberg Journal of International Law 76 (2016), 193-202

Rinke, Stefan, Schadensersatzklagen gegen Staaten wegen schwerer Menschenrechtsverletzungen im Europäischen Zivilprozessrecht (Berlin: BWV Verlag 2016)

Sari, Aurel/Ramses A Wessel, 'International Responsibility for EU Military Operations: Finding the EU's Place in the Global Accountability Regime', in Bart Van Vooren/Steven Blockmans/ Jan Wouters (eds), The EU's Role in Global Governance: The Legal Dimension (Oxford: OUP 2013), 126-141

Zimmermann, Andreas, 'Das Völkerrecht stärken!', Die Tageszeitung (13 September 2011), available at http://www.taz.de/!5112119/

Open Access This chapter is licensed under the terms of the Creative Commons Attribution 4.0 International License (http://creativecommons.org/licenses/by/4.0/), which permits use, sharing, adaptation, distribution and reproduction in any medium or format, as long as you give appropriate credit to the original author(s) and the source, provide a link to the Creative Commons license and indicate if changes were made.

The images or other third party material in this chapter are included in the chapter's Creative Commons license, unless indicated otherwise in a credit line to the material. If material is not included in the chapter's Creative Commons license and your intended use is not permitted by statutory regulation or exceeds the permitted use, you will need to obtain permission directly from the copyright holder. 